\title{
気管孔再発癌に対する外科的治療
}

一上縦隔郭清と食道抜去併用一

*小池 聰之, *小川 晃弘, *宇野 欽哉
**多幾山 涉

\section{Surgical Treatment for Stomal Recurrence of the Laryngeal Cancer : Application of the Mediastinal Dissection and Esophageal Stripping}

\author{
Satoshi Koike, M.D., Teruhiro Ogawa, M.D., \\ Kinya Uno, M.D. and Wataru Takiyama, M.D. \\ Shikoku Cancer Center Hospital, Matsuyama
}

Patients with laryngeal cancer generally visit a specialist in relatively early stage because of the horseness as a primary symptom. On the other hand, we see ocasionally the patients in advanced stage who need to have an emergency tracheostomy on the first visit. A part of such patients should be treated by the mediastinal dissection in addition to the routine radical neck dissection.

We report here two cases with stomal recurrences and one case with skin defect and esophageal fistula formation due to the radiotherapy after the laryngectomy.

They were operated on by the mediastinal dissection and esophageal stripping. The esophagus was successfully reconstructed by using the stomach.

Key words : 気管孔再発癌, 縦隔郭清, 食道抜去

\section{1.はじめに}

癌の早期発見，早期治療の啓蒙運動のため頭 頸部領域に扔いても早期癌の発見率が高まって きた。とりわけ，喉頭癌はその主症状が嗄声で あるため比較的早期に専門医を受診する。

しかし，来院時，緊急気管切開を必要とする 進行癌症例にも遭遇することがある。

進行癌症例は, 通常頸部リンパ節転移を伴っ ており, 根治的頸部リンパ節郭清に加え, 縦隔 郭清を必要とする症例もある。

今回, われわれは喉頭全摘後, 気管孔周囲に

*国立病院四国がんセンター耳鼻咽喉科

**同外科
再発した 2 症例と喉頭全摘後の追加照射によ り，前頸部に皮膚欠損と食道瘦孔を生じた症例 に対し, 上縦隔郭清と食道全抜去後, 胃管挙上 にて食道を再建した。

症例の紹介と気管孔再発癌の発生因子に関し て文献的考察を加えて報告する。

\section{2. 症例}

症 例 $1: 66$ 歳, 男性

現病歴: 喉頭癌 (T3N0M0) supra glottic type, 扁平上皮癌, 呼吸困難で緊急気管切開を 受けたのち, 術前 $30 \mathrm{~Gy}$ 照射後, 昭和 58 年 12 月 19 日単純喉頭全摘を受けた。術後4.5力月で気管孔 周囲に再発したため, リニアックを $56 \mathrm{~Gy}$ 照射 
するも腫瘍は全く縮小しないため手術目的にて 紹介来院した。

局所所見：気管孔を取り囲むように拇指頭大 の腫瘤 3 個と鶏卵大の腫瘤が存し, 一部自潰し て癌乳と壊死物質が気管孔に流入していた（写 真 1)。また，右下顎角にも拇指大のリンパ節転 移を認めた。

食道透視を行うと, 頸部食道は気管孔の部位 で腫瘍のため左外方へ圧排され狭窄像を呈して いた。しかし，バリウムの通過は良好で，粘膜 面は正常であった。

以上の所見より, 上縦隔郭清, 前頸部皮膚切 除を含め食道全抜去, 胃管挙上による食道再建 を予定とし昭和 60 年 8 月 9 日根治手術を行っ た。

皮切は写真 1 のごとく McFee の皮切に準じ て気管孔周囲の皮膚切除, 胸骨柄, 右鎖骨 $1 / 3$ 切 除を行い右根治的頸部リンパ節郭清を行った。

上縦隔を郭清し, 腫瘍を一塊とし, 食道を非 開胸下に全抜去し(写真 2 ), 気管を腕頭動脈の 下をくぐらせ，前胸壁皮膚へ縫合する mediastinal tracheostomaを作製した。

食道は胃管にて再建し，前頸部皮膚欠損部に は右大胸筋筋皮弁 $(10 \times 9 \mathrm{~cm})$ を用いて修復し た(写真 3 )。

摘出標本の病理組織所見は, 腫瘍は気管孔を 中心に皮下にびまん性浸潤し, 内腔は癌潰瘍を 形成していた。気管孔に相当する食道前壁には 腫瘍の直接浸潤を粘膜下まで認めた。非角化型 扁平上皮癌, INF $\beta, 1 \mathrm{y}+2, \mathrm{v}+1$ であった。

脈管侵襲が強いため, シスプラチンを中心と する多剂併用化学療法を 1 クール行い昭和 61 年 10月10日退院した。退院 4 力月後, 左耳下腺部, 右腋下部に転移性腫瘤が出現したため, 放射線 $60 \mathrm{~Gy}$ 照射後, シスプラチンを中心とする多剤 併用化学療法を 2 クール行うも腫瘍は縮小せ ず，昭和 61 年 6 月 17 日悪液質のため他施設で死 亡した。

症 例 $2: 62$ 歳, 男性

現病歴: 喉頭癌 (T3N0M0), subglottic type, 扁平上皮癌。呼吸困難で緊急気管切開を 受けたのち, 術前 $40 \mathrm{~Gy}$ 照射を行い, 昭和59年 7 月 3 日甲状腺を含め喉頭全摘を受けた。

術後 1 年 8 力月，右鎖骨上窩加気管孔右側
に $6 \times 6 \mathrm{~cm}$ の硬い腫瘤が出現したため, 手術目 的にて紹介来院した。

食道透視で頸部食道は再発腫湯により左方に 圧排され狭窄があったが, 粘膜面は正常であっ た (写真 4$)$ 。

本症例も症例 1 と同様の術式で昭和 61 年 4 月 22日根治術を行った。

皮切はU字型皮切に胸骨上に縦切開を加え胸 骨柄，右鎖骨 $1 / 2$ を切除した (写真 5 )。腫瘍は 食道に浸潤していたため, 非開胸下に食道全抜 去し胃管挙上にて食道を再建した。気管は腕頭 動脈の下方をくぐらせ，前胸壁皮膚へ縫合する mediastinal tracheostomaを作製した（写真 6 )。

脈管侵襲が強いため補助化学療法を行ってい るが，術後11力月経過するも再発なく健在であ る(写真 7 )。摘出標本の病理組織所見は, 非角 化型扁平上皮癌, $\mathrm{INF} \beta, 1 \mathrm{y}+2, \mathrm{v}+1$ であった。 気管孔再発腫瘍に対応する食道には, 癌が粘膜 下まで直接浸潤していた。

症 例 $3: 80$ 歳, 男性

現病歴：昭和 42 年 3 月喉頭癌（T3N0M0）に て喉頭全摘, 術後コバルトによる放射線治療(照 射線量不明) を受けた。放治後 3 年頃より前頸 部皮膚, 胸骨柄, 胸鎖関節が壊死となり, 昭和 56 年 9 月 21 日来院時には前頸部皮膚欠損 $(35 \times$ $55 \mathrm{~mm}$ ）と食道壁にも $1 \times 1 \mathrm{~mm}$ の小さな㾇孔 を形成していた。皮膚欠損部周囲の皮膚は幅 5 $\mathrm{cm}$ にわたり色素沈着や瘢痕性拘縮を呈してい た。

患者は自宅において自分自身で食道瘦孔を大 綿球で圧迫して食事を摂取していたが次第に㿉 孔が拡大し, 唾液, 食事が気管孔へ流入し嬹下 性肺炎, 気管孔よりの出血も生じたため, 2 年 5 力月の自宅療養後昭和 61 年 5 月 21 日緊急入院 した。

局所所見: 前頸部皮膚の欠損部は60×70 $\mathrm{mm}$ に拡大していたが，創は上皮化していた。 胸骨柄も腐骨となり, 露出している気管軟骨は 上皮化していた（写真 8 )。食道瘻孔注 $10 \times 5$ $\mathrm{mm}$ となり, 唾液流出が著しかった。両側総頸 動脈は皮膚欠損部に露出していたが線維性に上 皮化していた。血管造影を行うと，皮膚欠損部 の総頸動脈は狭窄を生じ通常の $1 / 3$ にってい 


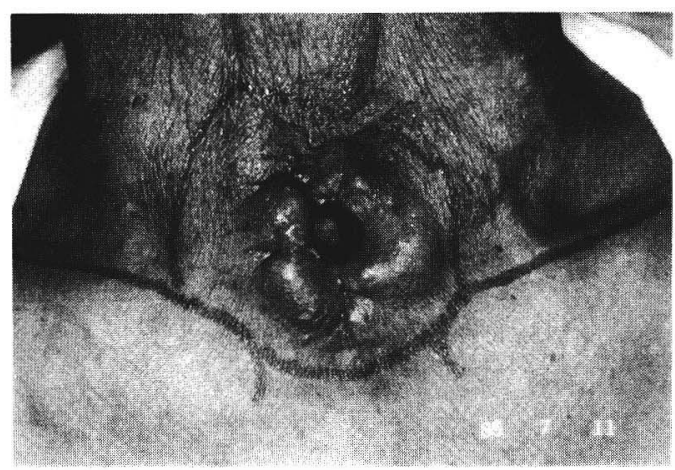

写真 1 気管口を取り囲む腫瘤と皮膚切開線

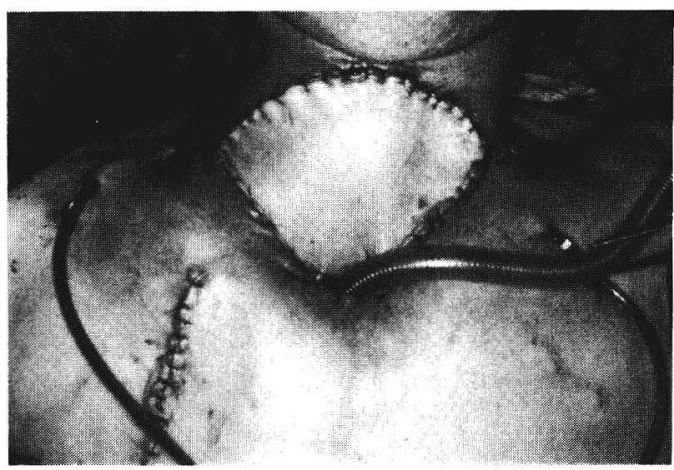

写真 3 前頸部皮膚欠損を大胸筋皮弁で修復

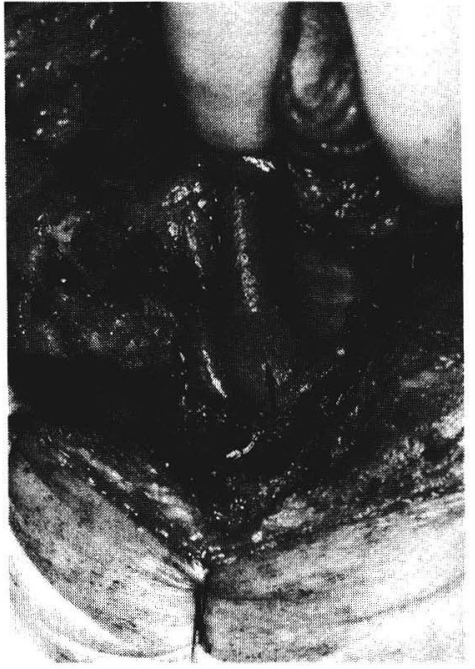

写真 2 上縦隔を郭清し, 腫瘍を 挙上(矢印は腕頭動脈)

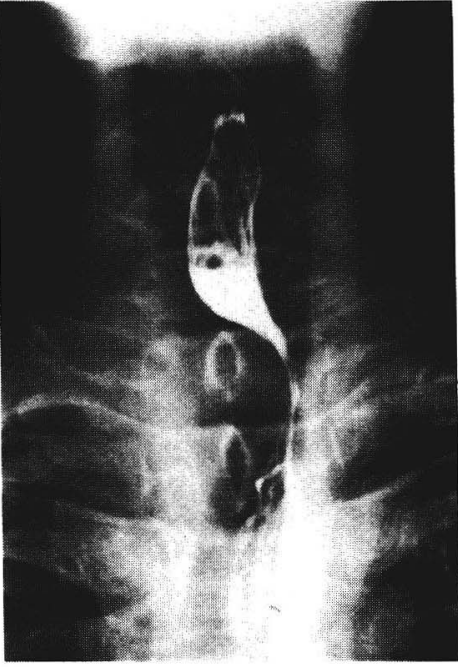

写真 4 食道は腫瘍により左方へ 圧迫され狭窄を呈す

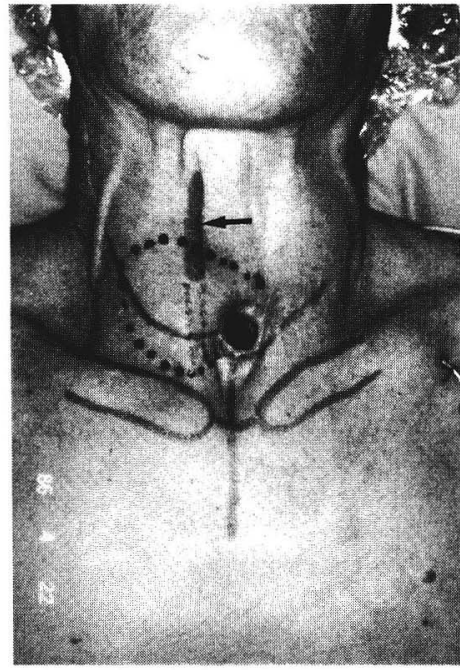

写真 5 点線の部：再発腫瘤 矢印：頸動脈。

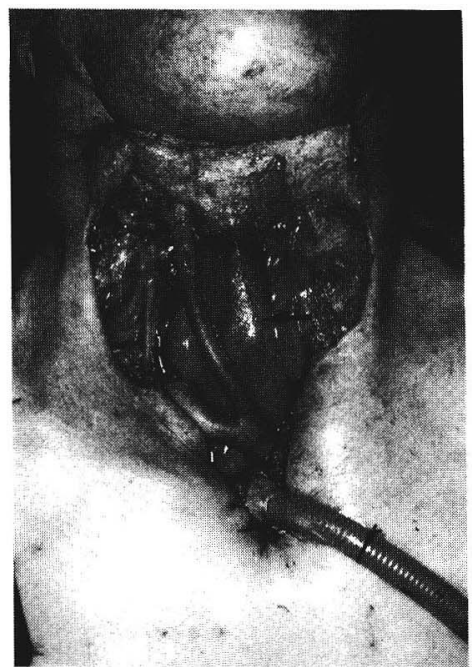

写真 6 気管を腕頭動脈下方へinterposition L mediastinal stomaを作製 (矢印牥胃管)

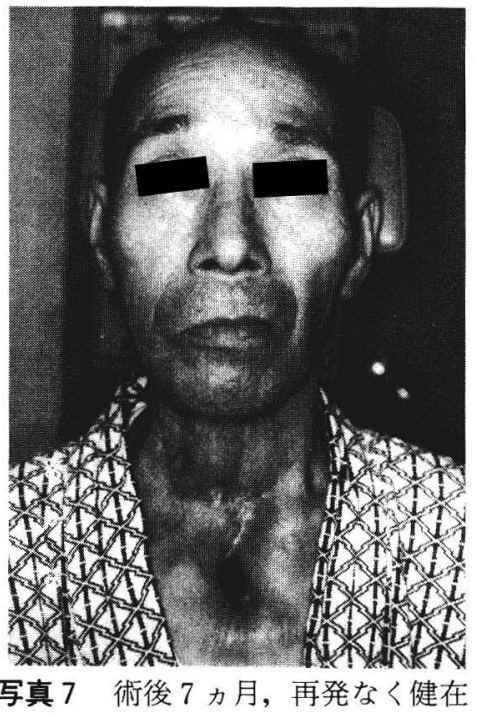

写真 7 術後 7 力月, 再発なく健在 


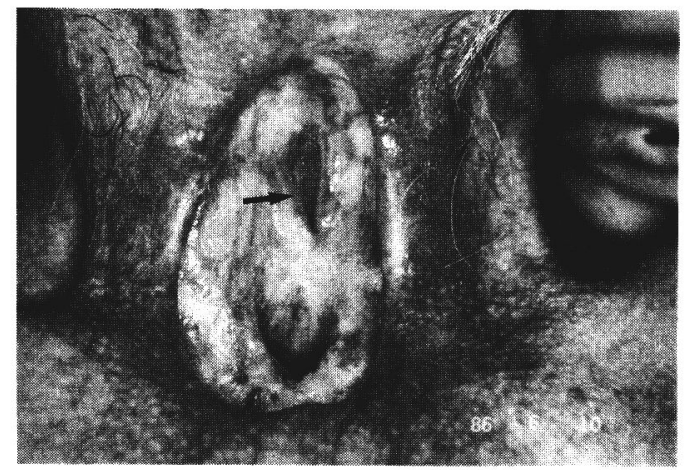

写真 8 前頸部は皮膚欠損 $(60 \times 70 \mathrm{~mm})$ あり 矢印は食道瘻孔 $(10 \times 5 \mathrm{~mm})$ 。

た。内科的な全身検索においても，老人性変化 のみで performance status は 1 であったため, 根治術を行った。写真 9 のように皮膚欠損部よ り上下, 左右に $30 \mathrm{~mm}$ 離して健状部皮膚に皮切 をおき, 両胸鎖関節切除, 胸骨䋛切開を併用し た。食道全抜去後, 胃管にて食道を再建し前頸 部皮膚欠損を大胸筋皮弁で修復した（写真10)。

術中, 血圧の変動, 血液ガスも著変なく手術 を終了したが，術翌日の覚醒が不良のためCT 検査を行ったところ, 多発性の脳梗塞が生じて いた。以後, 集中治療を行うも術後 12 病日で死 亡した。

\section{3. 考按}

喉頭癌は頭頸部腫瘍の中では，根治性の高い 疾患である。しかし，喉摘後の気管孔再発癌に 対し化学療法や放射線療法のみでは, 一時的な 治療効果は得られても，これのみで完治すると は到底考えられないため搪大手術が必要となっ てくる。

気管孔再発癌の発生頻度について, Keim¹ ら は喉摘116例中17例 (14.6\%), Modlin and Ogura $^{2)} 243$ 例 中12例 ( $5 \%$ ), Myers and Ogura $^{3)}$ は452例中33例 (7.2\%), Bonneau ら ${ }^{4)}$ は 92例中 11 例（12\%）と，その発生率には報告者 により差がある。

その原因として腫暄の部位，大きさ，頸部り ンパ節転移の有無, 緊急気管切開などいろいろ の原因が報告されている。

腫瘍の部位および大きさについて Bonneau ら ${ }^{4)}$ の報告した気管孔再発癌11例中, 下咽頭に

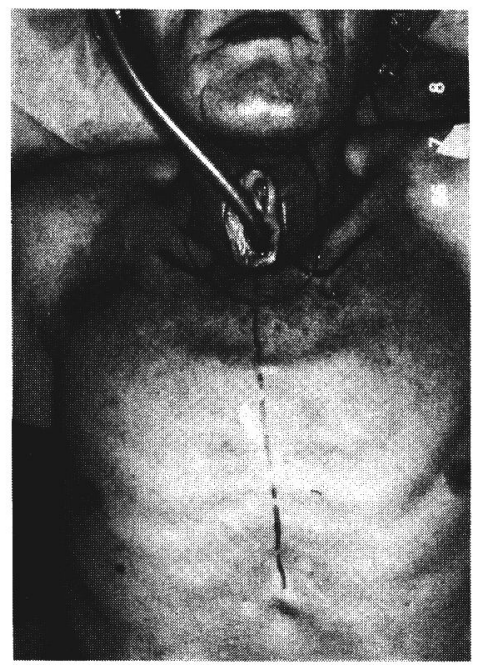

写真 9 皮膚欠損部より上下, 左右 $30 \mathrm{~mm}$ の 皮膚を合併切除

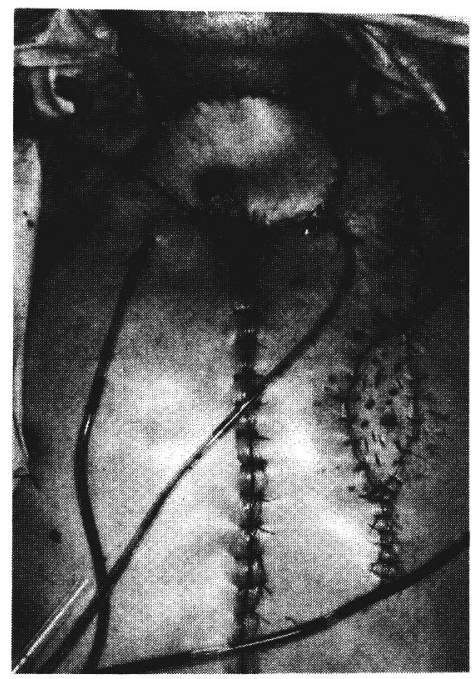

写真10 前頸部皮膚欠損を大胸筋皮弁で修復

原発巣を有する 1 例を除く 10 例を部位別に検討 すると，声門上癌では $3 / 51$ (5.8\%)，声門下腔 進展癌では7/19（36.8\%）と多発している。 Myers and Ogura ${ }^{3)}$ の報告では, 気管孔再発癌 33例中口腔，下咽頭に原発巣を有する 7 例を除 外すると, 喉頭癌の気管孔再発癌は26例となる。 その内訳は声門下腔進展例では15例, 進展して いない症例では11例であり，その気管孔再発癌 の発生頻度に大差はない。

しかし，声門下腔進展例で腫崵の占居部位が transglottic type であるものは，そうでない症 
例の 2 倍の発生率を示している。Modlin and Ogura ${ }^{2)}$ の報告でも下咽頭原発巣を除外して検 討すると声門下腔進展癌症例は, 進展のない症 例の 3 倍の気管孔再発癌をみている。

腫瘍との大きさに関しては2), 実測できない が腫瘍の最大長 $2 \mathrm{~cm}$ 以上で, かつ, transglottic typeの声門下腔進展症例に多く見られ た。

緊急気管切開と気管再発癌とは関係があると 報告している論文と無関係と述べている論文が ある。

Keim ら の報告によると, 緊急気管切開した 22 例中 9 例 $(40.9 \%)$ に気管孔再発癌をみるが, 喉摘時気管切開した症例や気管内挿管で手術し た症例ではそれぞれ4/29（13.9\%)，4/65（6.1 \%)とその発生率は低い。

また, Loewy and Laker ${ }^{5}$ は緊急気管切開症 例は $2 / 11 （ 18.3 \%)$ に気管孔再発癌をみるが, 喉摘時の気管切開症例では $2 / 78(2.6 \%)$ となり， 気管内挠管では355例中まったく再発癌を見な かったと報告している。

この事実より，緊急気管切開が気管孔再発癌 の原因と考えて, Hoover and King'), Baluyot ${ }^{7)}$ は, 緊急気管切開を要する症例に対しては緊急 喉頭全摘を行うほうが気管孔再発癌を減少さす ために有効と報告している。

一方，Modlin and Ogura ${ }^{21}$ 性，気管孔再発癌 症例を分析して緊急気管切開と気管孔再発癌の 発生頻度は相関ないと言っている。

われわれの症例は 2 例とも術前緊急気管切開 が行われており，気管孔再発癌と密に関係があ るように見えるが，第 1 症例は supraglottic type であり，その原因は傍気管りンパ節郭清が 不完全のためと考える。第 2 症例は声門下腔進 展癌のため, 甲状腺全摘，傍気管リンパ節を郭 清した。しかし, 術後 1 年 8 力月で気管孔再発 癌を生じた。再発の原因は明白ではないが，手 術材料より臨床病理学的に検討すると脈管侵襲 が強いためと考える。

気管孔再発癌に対する手術療法は, その浸潤 範囲を食道 XP，血管造影， CT などで的確に診 断することに始まる。

手術に際し大多数の症例で, 食道粘膜は正常 でも筋層に浸潤しているので食道全抜去，胃管
による食道再建が必要となるため外科とのチー 么医療が重要と考える。

また，大きな手術を行うのであるから，その 根治切除が可能か否かの判断が特に大切であ る。

村上8)9)によると, 腫瘍が縦隔内へ深く進展し ているもの，肺門リンパ節への転移を認めるも の, 脊椎前軟組織への浸潤あるものなどは根治 不可能と述べている。

われわれの第 1 症例, 第 2 症例は CT 検査で 頸動脈が腫瘍により取り囲まれていたが, 頸動 脈を外膜より剝離することができ, 根治術可能 であった。第 3 症例は CT 検査で上䋛隔の瘢痕 と大血管との関係が明白には判明しなかった が，喉摘術19年経ており，また，放射線過量照 射が原因で組織壊死を生じていたので，上縦隔 は郭清せず食道再建に的をしぼって手術を行っ た。

手術時，胸骨柄，鎖骨の部分切除を併用する と，上縦隔郭清により生ずる死腔を小さくする のみならず，再発腫瘍と大血管群との関係を明 視下におくことができ，より安全に手術が行え る。また, 皮膚を合併切除した症例では, 筋皮 弁を利用することによりその欠損修復のみなら ず死腔の充媜や大血管群に対する保護の上から も重要である。

気管孔再発癌は手術しても縦隔内の再発, 遠 隔転移を生じて予後不良な疾患である。

その予防のため, 最初の喉摘時, 外喉頭筋を その付着部で切断し, 傍気管リンパ節郭清を十 分行うことが気管孔再発癌に対する最大の予防 策と考える。

\section{4. 結 論}

1) 喉摘後，気管孔に再発した 2 症例と過量 照射により前頸部皮膚欠損を生じた症例に対 乙, 上縦隔郭清, mediastinal tracheostoma 作 製後，胃管挙上にて食道を再建した。

2）気管孔再発癌は声門下腔進展症例に多発 するため, 傍気管リンパ節郭清を十分に行い気 管切開は緊急気管切開の時も下気管切開を行う ことが重要である。

3 ) 縦隔郭清後の死腔の充媜と大血管群を保 護するために筋皮弁を用いるのは重要である。 
本論文の要旨は第38回日本気管食道科学会総会に おいて発表した。

\section{文献}

1) Keim, W.F. et al.: Study of post laryngectomy stomal recurrence. Arch. Otolaryngol., $81:$ 183-186, 1965.

2 ) Modlin, B. and Ogura, J. : Post-laryngectomy tracheal stomal recurrences. Laryngoscope, 79 : 239-250, 1969.

3 ) Myers, E.M. and Ogura, J.H. : Stomal recurrences: A clinicopathological analysis and protocol for future management. Laryngoscope, 89: 1121-1128, 1979.

4 ) Bonneau, R.A. and Lehman, R.H.: Stomal recurrence following laryngectomy. Arch. Otolaryngol., 101: 408-412, 1975.
5 ) Loewy, A. and Laker, H.I. : Tracheal stoma problems. Arch. Otolaryngol., 87 : 477-483, 1968.

6) Hoover, W.B. and King, B.D.: Emergency laryngectomy. Arch. Otolaryngol., 59 : 431-433, 1954.

7) Baluyot, S.T. et al.: Emergency laryngectomy. Arch. Otolaryngol., 94 : 414-417, 1971.

8 ）村上泰 - 他：喉頭癌術再発に対する手術治療と その限界，日耳鼻，81：195-203, 1978.

9 ）村上泰・他：前縦隔を経由する永久気管㜢造設 手術, 日気食会報, $28: 300-305 ， 1977$.

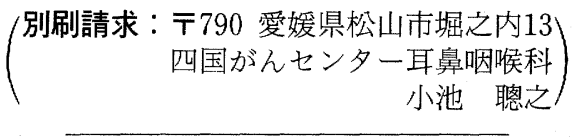

（投稿受付 1986 年11月10日） 